\title{
Computer Attitude of Prospective Teachers in Relation to Emotional Intelligence
}

\author{
Pooja Grover \\ Research Scholar, Malwa Central College of Education for Women, Ludhiana, Punjab
}

\begin{abstract}
The study was intended to predict Computer Attitude of prospective teachers of government aided and private college on the basis of their Emotional Intelligence. The sample consisted of total 200 students; 100 students being selected randomly from each government aided and private college of Ludhiana city. Computer Attitude Scale (CAS) by Khatoon and Sharma (2011) and Emotional Intelligence Test (EIT) by Zainuddin and Ahmed (2011)were used to collect the data. The results of the study showed significant positive relationship between Computer Attitude and Emotional Intelligenceof prospective teachers, also between Computer Attitude and of Emotional Intelligenceprospective teachers studying in government aided college and private college.
\end{abstract}

Keywords: Computer Attitude, Emotional Intelligence, Prospective Teachers

\section{Introduction}

The use of computer-based technology for the delivery of educational content is growing rapidly. Knowledge of the computer related skills and techniques widens one searning horizon and potential that in turn promotes a positive feeling towards the computer (Houtz\& Gupta, 2001).Successful integration of information and communication technology in any educational institution depends on the competence and the attitude of teachers towards the role of such technologies in teaching and learning.Thus, for the effective use of such technology, teachers must have the competence and right attitude towards technology (Kadel, 2005).Emotions also play a significant role in guiding and directing our behaviour. Emotions are important in establishing a positive learning environment especially in human computer interaction (Cristescu, 2008).Emotions in the learning process motivate learning, facilitate self-regulated processes and produce different problem solving processes. Thus, learneres emotion not only affects the le arning process but also has significant impact on computer usage (Goldsworthy, 2002). Earlier studies have also shown that positive and negative emotions are the psychological basis of cognition and behaviour changes within computer based or web learning and further direct the learner behaviours (Kang, Kim \& Chong, 2011; Kim, 2008; Lee \& Song, 2007;

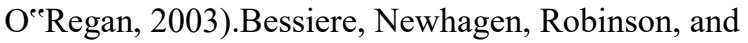

Shneiderman (2006) also remarked that frustration is the emotional outcome of a negative technology experience.Students with higher emotional intelligence were found to be innovative and highly motivated (Mayer, Roberts, \&Barsade, 2008) as compared to those who possess immature levels of emotional intelligence who may be inclined to perceive learning with technology negatively, as it requires self-discipline, independent effort, maturity, time management skills, and positive attitudes (Berenson, Boyles \& Weaver, 2008).Thus, there is a need to provide conducive environment for pre-service teachers to experience success in using the computers for making teaching and learning more effective.

\section{Attitude}

Attitude is a mental state of readiness influencing individual ${ }^{\text {ee }} \mathrm{s}$ response to an object or a situation. Positive attitude of an individual enhance the learning process whereas negative attitude leads to resistance towards in any task. Wang, Chen and Shi (2007) supported the multidimensionality concept of attitude towards computers.Since, attitudes are learnt; they can be changed with experience of stimulus objects and with social rules or institutions (Binder \&Niederle, 2007). The construct "attitudese ${ }^{\text {ee }}$ was divided into four different variables as computer liking; computer anxiety; computer confidence and perceived usefulness of the computer by Loyd and Gressard (1984).

\section{Computer Attitude}

A person"s performance with the technology and the satisfaction drawn with the experience is determined by his/her attitude towards computers. Individuals having positive computer attitude will be able to use computers in a better way and perform better as compared to the ones having negative computer attitude as they will be reluctant to use computers.Computer Attitude relates to users ${ }^{\text {ee }}$ interaction with computer hardware, computer software, other persons relating to computers, and activities that involve computer use. Brown and Inouye (1978) suggest that exposure to computer-related devices may be a factor in determining one ${ }^{\text {ee }} \mathrm{s}$ attitudes toward computers. Computer attitudes are influenced by different variables like knowledge about computers (Derscheid, 2003), gender (Bebetsos\& Antoniou, 2009), liking (Yildirim, 2000) and computer experience (Deniz, 2007). Khine (2001) found that there exists a significant relationship between computer attitude and its use in institutions for pre-service teachers and also for serving teachers in the affective attitude, general usefulness, behavioural control, and pedagogical use (Yuen \& Ma, 2002).Whitrow (1999) highlighted that computerrelated attitudes influence students ${ }^{\text {ee }}$ desire to use computers, enrol in computer-related subjects and their choice of career path. Students ${ }^{\text {ee }}$ computer -related attitudes are also directly related to their prior experiences and use of computers (Levine \&Donitsa-Schmidt, 1997). Users" attitudes toward 


\section{International Journal of Science and Research (IJSR) \\ ISSN (Online): 2319-7064}

Index Copernicus Value (2013): 6.14 | Impact Factor (2015): 6.391

computers influence the future use of and behaviour toward computers (Woodrow, 1991) and acceptance of computers (Selwyn, 1997).

\section{Emotional intelligence}

Emotional intelligence is the ability to recognize your emotions, understand what they are telling you, and realize how your emotions affect people around you and your perception of others. Salovey and Mayer (1990) defined emotional intelligence (EI) as "the ability to monitor one"s own and otherse feelings and emotions, to discriminate among them and to use this information to guide onees thinking and actions."

Goleman (1995) gave five domains of emotionalintelligence as:

- Self-awareness: It is the capacity for understanding one's emotions, one's strengths, and one's weaknesses. The ability to recognize a feeling as it is happening is fundamental to emotional intelligence. If you are unable to notice your emotions, you can be overwhelmed and can flounder at the mercy of these strong feelings.

- Managing emotions: It is the ability to maintain an even keel or bounce back quickly from life's upsetting developments builds on the preceding skill. You want to have a sense of control over your emotions so that you can deal with them appropriately.

- Self-motivation: It is the ability to marshal our emotions for the accomplishment of any sort of goal. For creative tasks, focus and mastery are important skills, and emotional control is essential.

- Recognizing the emotions of others: „People ${ }^{c e}$ skills are based on a capacity for empathy and the ability to stay tuned to the emotions of others. Empathy kindles altruism and lies at the basis of professions that deal with caring for others, such as teaching, management, and the healing arts.

- Handling relationships: Interpersonal effectiveness is dependent on your ability to manage the emotions of others. Brilliant projects and innovative insights are often never realized because of a lack of social competenceand leadership skills.

Thus, competency in all these aspects is needed by an individual for his success in different aspects of life.

Petrides and Furnharm (2001) described emotional Intelligence as"a constellation of emotion-related selfperceived abilities and dispositions located at the lower levels of personality hierarchies". Emotional intelligence has also been found to be related to students ${ }^{\text {ee }}$ academic achievement, behaviours and attitudes (Salami \&Ogundokun, 2009; Wong, Wong \& Chau, 2001).Thus, emotional intelligence means management of emotions. It refers to individual differences in the perception, processing, regulation and utilization of emotional information. Positive and negative emotions of a person affect his ability to perform any task as a person with high emotional intelligence will be emotionally more stable, motivated, and self-confident will perform better in a task as compared to the one having low emotional intelligence.

\section{Review of Related Literature}

\subsection{Computer Attitude and Emotional Intelligence}

Earlier studies have indicated that emotion was an indicator of the degree of efforts computer users exerted on specific tasks (Rozell and Gardner, 2000).A significant relationship between Internet experience and the emotional state of computer users has also been established (Lazar, Feng \& Allen, 2006).

Kumar, Muniandy and Yahaya (2012) studied the relationship between emotional intelligence and attitudes towards computerin the students of final year diploma of electronic engineering (computers) in polytechnics in the northern region of Malaysia. Data was collected from 42 engineering students. Results of this study showed that the relationship between emotional intelligence and attitude towards computer was positive but very weak. Significant difference were found when gender was compared as female student's emotional intelligence was negatively correlated with attitude towards computers, whereas male students correlation was more positive and stronger.

Behnke (2012) of Purdue University, United States examined the relationship between students' attitudes towards computer based instruction and their emotional intelligence. The emotional intelligence of 33 postsecondary hospitality students was assessed using Bar-On'sEQ-i:S. The results showed that as students' ESI increased, their attitude towards the computer-based instruction also increased. Students with average-high ESI expressed significantly more positive attitudes towards the instruction than those with low-average ESI.

Agbatogun, Ajelabi and Oyewusi (2011) investigated the relative and combined contributions of cognition and emotion to Nigerian undergraduates ${ }^{\text {ee }}$ level of computer frustration in online environments. The 1972 students who participated in the study were randomly selected from the two state-owned universities in Ogun State, Nigeria. The research findings revealed that the students ${ }^{\text {ce }}$ computer frustration negatively and significantly correlated with cognition but positively and significantly correlated with emotion.

Vuorela and Nummenmaa (2004) studied what events cause emotional reactions when students use a web-based learning environment (WBLE) in their studies, and how the emotions experienced while using the WBLE, emotion regulation strategies and computer self-efficacy are related to collaborative activities in the environment. Data was collected from undergraduate students from seven Finnish universities who participated in a five-week national webcourse of the program in educational use of information and communication technologies. Participants ${ }^{\text {ee }}$ ages ranged from 18 to 52 years. The results showed that both emotional reactions and their effective regulation affect student participation in collaborative activities in a WBLE andusing reappraisal as emotion regulation strategy led to increased activity in the environment. There was a moderately strong association between students ${ }^{\text {ee }}$ computer self-efficacy and mean arousal. 


\section{International Journal of Science and Research (IJSR) \\ ISSN (Online): 2319-7064 \\ Index Copernicus Value (2013): 6.14 | Impact Factor (2015): 6.391}

Al-Faouri (2011) examined the influence of emotional intelligence dimensions i.e. interpersonal self-awareness, self-confidence, and self-discipline, as well as intrapersonal empathy, optimism, and social responsibilityon technology learning process levels. An empirical study with a questionnaire was conducted on 124 voluntary respondents from 10 IT organizations in Jordan. The results showed that employees with a good ability to understand and trust their own feelings and preferences, to have belief in themselves, and to be self-motivated seem to have higher basic technology learning process levels abilities such as dealing effectively with stressful situations.

\section{Emergence of the Problem}

Emotions play a vital role in affecting users ${ }^{\text {ee }}$ attitude towards computers. There is very little research available on the effect of emotional intelligence on learning with technology (Al-Faouri, 2011). The relative lack of consideration of emotional factors has been discussed as a partial reason for high drop-out rates in the e-learning context (Im, 2007; Rowe, 2006). Thus, present study was taken to study the computer attitude of prospective teachers in relation to their emotional intelligence. The review of literature cited above shows that very little research is available on computer attitude and emotional intelligence and the studies showing relation between computer attitude and emotional intelligence have been conducted in foreign countries like Malaysia (Kumar, Muniandy\&Yahaya, 2012), U.S.A (Behnke, 2012) and Nigeria (Agbatogun, Ajelabi\&Oyewusi, 2011). Thus, this gap can be filled byexamining the computer attitude of prospective teachers in relation to their emotional intelligenceso as to develop emotionally intelligent teachers who are motivated towards the use of technology in teaching and learning thereby making it more effective.

\section{Objectives}

- To investigate the significance of relationship between Computer Attitude and Emotional Intelligence of prospective teachers.

- To study the significance of relationship between Computer Attitude and Emotional Intelligence of prospective teachers studying in government aided colleges.

- To investigate the significance of relationship between Computer Attitude and Emotional Intelligence of prospective teachers studying in private colleges.

\section{Hypotheses}

$\mathrm{H}_{01 \mathrm{a}}$ There will be no significant relationship between Computer Attitude and Emotional

Intelligenceof prospective teachers.

$\mathrm{H}_{01 \mathrm{~b}}$ There will be no significant relationship between Computer Attitude and Emotional

Intelligence of prospective teachers studying in government aided college.
$\mathrm{H}_{01 \mathrm{c}}$ There will be no significant relationship between Computer Attitude and Emotional

Intelligenceof prospective teachers studying in private college.

\section{Sample}

Sampling is an essential part in the field of research providing generalizations on the basis of small proportion of the population and produces precise and accurate results. Two stage randomization technique was used in this study. Sample consisted of total 200 students; 100 students being selected randomly from each government aided and private college of Ludhiana city.

\section{Tools}

- Computer Attitude Scale (CAS) by Khatoon and Sharma (2011).

- Emotional Intelligence Test (EIT) by Zainuddin and Ahmed (2011).

\section{Results and Discussion}

\subsection{Relation between Computer Attitude andEmotional Intelligence}

Table 1: Relation between Computer Attitude and Emotional Intelligence of prospective teachers ( $\mathrm{N}=200)$

\begin{tabular}{|c|c|}
\hline Variables & $r$ \\
\hline Computer Attitude with Emotional Intelligence & $0.253^{*}$ \\
\hline
\end{tabular}

*Correlation is significant at 0.05 level (0.197)

Table 1 reveals that the value of correlation between Computer Attitude and Emotional Intelligence of prospective teachers is 0.253 . This value is positive and significant $(\mathrm{p}<0.05)$. Therefore, it can be concluded that Computer Attitude has significant positive relation with Emotional Intelligence among prospective teachers studying in government aided college. Thus, hypothesis $\mathrm{H}_{02 a}$ which states that "There will be no significant relation between Computer Attitude and Emotional Intelligence of prospective teachers", is rejected.

Table 2: Relation between Computer Attitude and Emotional Intelligence of prospective teachers studying in government aided college $(\mathrm{N}=100)$

\begin{tabular}{|c|c|}
\hline Variables & $r$ \\
\hline Computer Attitude with Emotional Intelligence & $0.234^{*}$ \\
\hline
\end{tabular}

Table 2 reveals that the value of correlation between Computer Attitude and Emotional Intelligence of prospective teachers studying in government aided college is 0.234 . This value is positive and significant $(p<0.05)$. Therefore, it can be concluded that Computer Attitude has significant positive relation with Emotional Intelligence among prospective teachers studying in government aided college. Thus, hypothesis $\mathrm{H}_{02 \mathrm{~b}}$ which states that "There will be no significant relation between Computer Attitude and Emotional Intelligence of prospective teachers studying in government aided college", is rejected. 


\section{International Journal of Science and Research (IJSR) \\ ISSN (Online): 2319-7064 \\ Index Copernicus Value (2013): 6.14 | Impact Factor (2015): 6.391}

Table 3: Relation between Computer Attitude and Emotional Intelligence of prospective teachers studying in private college $(\mathrm{N}=100)$

\begin{tabular}{|c|c|}
\hline Variables & $r$ \\
\hline Computer Attitude with Emotional Intelligence & $0.279^{*}$ \\
\hline
\end{tabular}

*Correlation is significant at 0.01 level (0.256)

Table 3 reveals that the value of correlation between Computer Attitude and Emotional Intelligence of prospective teachers studying in private college is 0.279 . This value is positive and significant $(\mathrm{p}<0.01)$. Therefore, it can be concluded that Computer Attitude has significant positive relation with Emotional Intelligence among prospective teachers studying in private college. Thus, hypothesis $\mathrm{H}_{02 \mathrm{c}}$ which states that "There will be no significant relation between Computer Attitude and Emotional Intelligence of prospective teachers studying in private college", is rejected.

\section{Discussion}

The result is well supported by the studies conducted earlier byKumar, Muniandy and Yahaya (2012),Behnke (2012) and Al-Faouri (2011).Studies also show that students who had high emotional intelligence were intrinsically motivated and developed more positive attitude toward learning (Salami, 2010).

\section{Conclusions}

- There exists significant positive relationship between Computer Attitude and Emotional Intelligence of prospective teachers.

- There exists positive and significant relationship between Computer Attitude and Emotional Intelligence of prospective teachers studying in government aided college.

- There exists significant positive relationship between Computer Attitude and Emotional Intelligence of prospective teachers studying in private college.

\section{Educational Implications}

The results of the study reveal significant positive relationship between Computer Attitude Emotional Intelligence. It is thus suggested that to improve the Attitude towards Computer of Prospective Teachers, conditions conducive for the development of Emotional Intelligence must be created. The improvement in Emotional Intelligence will lead to the improvement of Computer Attitude.

\section{References}

[1] Agbatogun, A.O., Ajelabi, P.A. \&Oyewusi L.M. (2011). The influence of cognition and emotion on Nigerian undergraduates $^{e e}$ frustration during e-registration. ASEAN Journal of Teaching and Learning in Higher Education(AJTLHE),3(1), 1-11.

[2] Al-Faouri, A.H.A. (2011). Investigating the impact of emotional intelligence on technology learning.
International Journal of Engineering and Technology, 11(3), 58-78.

[3] Bebetsos, E. \& Antoniou, P. (2009). Gender differences on attitudes, computer use and physical activity among Greek university students. The Turkish Online Journal of Educational Technology(TOJET), 8(2), 63-67.

[4] Behnke, C (2012). Examining the relationship between emotional intelligence and hospitality student attitudes toward E-learning. Journal of Hospitality and Tourism Education, Special Edition, 24(2), 12-20.

[5] Berenson, R., Boyles, G., \& Weaver, A. (2008). Emotional Intelligence as a Predictor for Success in Online Learning. The International Review of Research in Open and Distance learning, 9(2), Online available: http://www.irrodl.org/index.php/irrodl/article/view /385/1036.

[6] Bessiere, K, Newhagen, J.E, Robinson, J.P \&Shneiderman, B. (2006). A model for computer frustration: The role of instructional and dispositional tutors on incident, session and post- session frustration and mood. Computers in Human Behavior, 22, 941961.

[7] Binder, M. \&Niederle, U. (2007). Institutions as determinants of preference change- a one way relation? Papers on Economic Evolution Number 0607 retrieved on 25th March 2009 http://papers.econ.mpg.de/evo/discussionpapers/200607.pdf

[8] Brown, I. \& Inouye, D. (1978).Learned helplessness through modelling: the role of perceived similarity in competence. Journal of Personality and Social Psychology, 36, 900-908.

[9] Cristescu, I. (2008). "Emotions in Human-Computer Interaction: The Role of Nonverbal Behaviour in Interactive Systems". InformaticaEconomică, 2(2), 110116.

[10]Deniz, L. (2007). Prospective Class Teacherse Computer Experiences and Computer Attitudes. International Journal of Social Sciences, 2(2), 116-122.

[11] Derscheid, C.L. (2003). Early childhood educator's attitudes toward and knowledge about computers in the classroom. (Unpublished Doctoral thesis), Northern Illinois University, Dekalb.

[12] Goldsworthy, R. (2002). Supporting the Development of Emotional Intelligence through Technology. Computers in the Schools, 19(1), 119-148.

[13] Goleman, D. (1995), Emotional Intelligence; Why It Can Matter More Than IQ. New York: Bantam Books, 37-43.

[14] Houtz, L. E., \& Gupta, U. G. (2001). Nebraska high school studentse computer skills and attitudes. Journal of Research on Computing in Education, 33 (3), 316326.

[15] Im. Y.W . (2007). A substantial study on the relationship between students' variables and dropout in Cyber University. Journal of the Korean Association of Information Education, 11(2), 205-219.

[16]Kadel, R. (2005). How teacher attitude affect technology. Learning and Leading with Technology, 39(5), 34-47.

[17] Kang, D.S., Kim, J.K. \& Chong, H.I. (2011). The structural relationship among affective characteristics, learning presence, learning flow, learning satisfaction in 


\section{International Journal of Science and Research (IJSR) \\ ISSN (Online): 2319-7064 \\ Index Copernicus Value (2013): 6.14 | Impact Factor (2015): 6.391}

distance education. The Journal of Educational Information and Media, 17(1), 133-152.

[18] Khatoon, T. \& Sharma, M. (2011). Manual for Computer Attitude Scale (CAS). Agra: National Psychological Corporation.

[19] Khine, M.S. (2001). Attitudes toward computers among teacher education students in Brunei Darussalam. International Journal of Instructional Media, 28(2), 147-153.

[20]Kumar, J.A., Muniandy, B. \&Yahaya, W.A.J.W. (2012). The Relationship between Emotional Intelligence and Students ${ }^{\text {ee }}$ Attitude towards Computers: A Study on Polytechnic Engineering Students. International Journal of Modern Education and Computer Science, 9, 14-22.

[21] Lazar, J., Feng, J. \& Allen, A. (2006). Determining the impact of computer frustration on the mood of blind users browsing the web. Paper at the 8th international ACM SIGACCESS conference on Computers and accessibility, Portland, Oregon, USA.

[22] Lee, S.M. \& Song, K.S. (2007). The effects of affective feedbacks according to the learner"s emotions in elearning. Journal of the Korea society of computer and information, 10(4), 125-133.

[23] Levine, T. \&Donitsa-Schmidt, S. (1997). Commitment to Learning: Effects of Computer Experience, Confidence and Attitudes. Journal of Educational Computing Research, 16(1), 83- 105.

[24] Loyd, B.H. \&Gressard, C. (1984). Reliability and factorial validity of computer attitude scales. Educational and Psychological Measurement, 44, 501505.

[25] Mayer, J.D., Roberts, R.D. \&Barsade, S.G. (2008). Emerging research in emotional intelligence. Annual Review of Psychology, 59, 507-536.

[26] O'Regan, K. (2003). Emotion and e-learning. Journal of Asynchronous Learning Network, 7(3), 78-92.

[27] Petrides, K.V. \&Furnham, A. (2001). Trait emotional intelligence: Psychometric investigation with reference to established trait taxonomies. European Journal of Personality, 15, 425-448.

[28] Rowe, J. (2006). Non-defining leadership. Kybernetes, 35(10), 1528-1537.

[29] Rozell, E.J. \& Gardner, W.L. (2000). Cognitive, motivation and affective processes associated with computer-related performance: A path analysis. Computers in Human Behavior, 16(2), 199- 222.

[30] Salami, S.O. \&Ogundokun, M.O. (2009). Emotional intelligence and self-efficacy as predictors of academic performance. Perspectives in Education, 25(3), 175185.

[31] Salami, S.O. (2010). Emotional intelligence, selfefficacy, psychological well-being and students ${ }^{\text {ce }}$ attitudes: implications for quality education. European Journal of Educational Studies, 2(3), 247-257.

[32] Salovey, P. \& Mayer, J.D. (1990). Emotional Intelligence. Imagination, Cognition, and Personality, 9, 185- 211.

[33] Selwyn, N. (1997). Students ${ }^{\text {ee }}$ attitudes toward computers: validation of a computer attitude scale for 16-19 education. Computers and Education, 28(1), 3541.
[34] Vuorela, M. \&Nummenmaa, L. (2004).Experienced emotions, emotion regulation and student activity in a web-based learning environment. European Journal of Psychology of Education, 19(4), 423-436.

[35] Wang, L., Chen, Y. \& Shi, J. (2007). Attitudes toward computers: a new attitudinal dimension. Cyber Psychology and Behavior, 10(5), 700-704.

[36] Whitrow, T.J. (1999). Integrating computers across the curriculum: students' computer-related attitude changes. (Unpublished B.Ed. Honours dissertation), School of Education, Flinders University, Adelaide.

[37]Wong, C., Wong, P. \& Chau, S. (2001). Emotional intelligence, students ${ }^{\text {ee }}$ attitude towards life and the attainment of education goals: An exploratory study in Hong Kong. New Horizons in Education- the Journal of Education, Hong Kong Teachers Association (HKTA), 44, $1-11$

[38] Woodrow, J.J. (1991). A comparison of four computer attitudes scales. Journal of Educational Computing Research, 7, 165-187.

[39] Yildirim, S. (2000). Effects of an educational computing course on pre-service and in-service teachers: a discussion and analysis of attitudes and use. Journal of Research on Computing Education, 32(4), 479-495.

[40] Yuen, H.K. \& Ma, W.K. (2002). Gender differences in teacher computer acceptance. Journal of Technology and Teacher Education, 10(3), 365-382.

[41] Yushau, B. (2006). Computer attitude, use, experience, software familiarity and perceived pedagogical usefulness: the case of mathematics professors. Eurasia Journal of Mathematics, Science and Technology Education, 2(3), 1-17.

[42] Zianuddin, R. \& Ahmed, A. (2011). Roqan Emotional Intelligence Test, Agra: National Psychological Corporation. 